\title{
INVESTIGATING THE EFFECT OF AQUEOUS EXTRACTS OF BASIL AND SAVORY ON ANTIOXIDANT ACTIVITY, MICROBIAL AND SENSORY PROPERTIES OF PROBIOTIC YOGURT
}

\author{
Zohreh Ghaleh Mosiyani, Rezvan Pourahmad ${ }^{\bowtie}$, Mohammad Reza Eshaghi \\ Department of Food Science and Technology, College of Agriculture, Varamin - Pishva Branch, Islamic Azad University \\ Varamin, Iran
}

\begin{abstract}
Background. The low viability of probiotics causes the short shelf life of fermented products. Therefore compounds which prolong the viability of probiotic bacteria can increase or at least maintain the healthbenefiting properties of these products. On the other hand, the addition of antioxidants is one of the methods to increase the shelf life of food products which has recently become more prevalent. In this respect, herbal extracts which are a good source of antioxidants can be appropriate alternative. The aim of this study was to evaluate the effect of adding basil and savory extracts on antioxidant activity, and on the microbial and organoleptic characteristics of probiotic yogurt.

Material and methods. The effect of adding basil extract ( $8 \%$ and $10 \%)$ and savory extract (6\% and $8 \%$ ) separately to low fat yogurt (1.5\% fat) containing Lactobacillus paracasei subsp. paracasei was investigated. The samples were stored at $4^{\circ} \mathrm{C}$. The viability of Lactobacillus paracasei subsp. paracasei, antioxidant activity and sensory properties of probiotic yogurt were evaluated on the $1^{\text {st }}, 7^{\text {th }}, 14^{\text {th }}$ and $21^{\text {st }}$ days.

Results. Basil and savory extracts significantly increased the viability of probiotic bacteria $(p<0.05)$. During storage, probiotic counts markedly decreased $(p<0.05)$ in comparison to the control sample. The addition of herbal extracts significantly increased antioxidant activity, but this activity decreased during storage $(p<0.05)$. The scores for taste, odor, color and overall acceptance decreased as herbal extracts increased, but there was no significant difference between the test samples and control sample in terms of the texture score $(p>0.05)$. During storage, there was no significant difference between the organoleptic scores of the samples $(p>0.05)$, but the taste score did increase significantly $(p<0.05)$.

Conclusion. It can be concluded that adding herbal extracts had a positive effect on the viability of probiotics and antioxidant activity of probiotic yogurt.
\end{abstract}

Keywords: basil, savory, extract, Lactobacillus paracasei subsp. paracasei, probiotic yogurt

\section{INTRODUCTION}

Following the growth of food product markets, the production of food with pleasurant flavor and health benefits like the prevention of diseases such as cardiovascular disease, cancers, osteoporosis etc. became competitive. In this respect, products with ingredients which have positive effects on human health in addition to their nutritional value have been manufactured. These products are so-called functional foods. Fortified foods with bio-active components such as probiotics and antioxidants, especially herbal antioxidants, are the most important and widely used functional components (Guarner et al., 2008). Probiotic 
bacteria are living organisms which inhabit the intestines after consumption and have positive effects on human health by improving natural microflora of the intestines. These microorganisms should belong to the natural microflora of the host and can tolerate acidic conditions (Ross et al., 2002). Lactobacillus paracasei is gram positive, mesophilic, microaerophilic, catalase+ and non-spore forming and also has good ability to produce acid (Mishra and Prasad, 2005). Dairy products lead in the development of functional foods. Therefore, probiotic yogurt is important in terms of biological activity, sensory properties and nutitional value. It should be mentioned that biological ability ought to be sufficient in order for enough organisms to reach the intestine after consumption. Storage of product and prevention of spoilage must be considered in addition to its nutritional value. We know that oxidation is the main problem which leads to a loss of nutritional quality, color, taste, texture and safety of food (Antolovich et al., 2002). In addition, free radicals come from oxidation have a negative effect on human health when they enter the food chain. In fact, the effect of free radicals on the development of diseases is obvious. Therefore, the effect of free radicals and active oxygen on diseases such as arteriosclerosis, cancer and premature aging is notable. One of the suitable ways to prevent oxidation or protect against damage by free radicals is to use antioxidants. These are ingredients which delay or modulate the oxidation of foods. In general, antioxidants are divided into two groups: chemical or synthetic and natural (Singh et al., 2007). Synthetic antioxidants which are widely used in food industries and have a phenolic structure include PG1, TBHQ2, BHT3 and BHA4, which postpone lipid oxidation (Kulisic et al., 2004). But due to the carcinogenic effect of these components and consumers' tendencies to use natural ingredients, natural antioxidants were taken into consideration (Yasin and Abou-Taleb, 2007). In this regard, in the last decades some studies have been conducted on the substitution of chemical ingredients for natural ones and several reports

\footnotetext{
${ }^{1}$ Propyl gallat.

${ }^{2}$ Tertiary butylhydro quinone.

${ }^{3}$ Butylated hydroxy toluene.

${ }^{4}$ Butylated hydroxy anisole.
}

mentioned that herbs have antioxidant or anti-radical components (Kulisic et al., 2004). A large group of these components are secondary metabolites of plants with a phenolic structure which be produced in situations where they encounter reactive oxygen species (ROS) and then produced in almost all plants and all of their parts. For these reasons in recent years, extraction of natural antioxidants from herbal sources has attracted a great deal of attention, particularly in the way several natural antioxidants which contain phenolic components were extracted from herbals (Stoilova et al., 2007).

Basil (Ocimum basilicum L.) contains various components such as monoterpenes like carrone, cineole, fenchone, geraniol, linanol, myrcene, thujone, ß-pinene, cis-ocimene, camphor, eugenol, methyleugenol and sesquiterpenoids like caryophyllene and $\alpha$-farnesol, D-germacrene. Furthermore, basil extract also contains terepnoid (uracilic acid) and flavoniod (appigenin) and this plant has high amounts of rosmarinic acid and caffeic acid (Sajjadi, 2006).

Summer savory (Satureja hortensis L.) contains components such as carvacrol (67\%), $\gamma$-terpinen $(15.3 \%)$ and $p$-semin $(6.73 \%)$. These components have antioxidant and antimicrobial properties (Sefidkon and Jamzad, 2005).

Amirdivani and Baba (2011) evaluated the changes in antioxidant activity, chemical properties and angiotensin converting enzyme inhibitory peptides in yogurt samples containing dill, peppermint and basil. Compared to the control yogurt at the end of fermentation and storage period, herbal yogurt had higher antioxidant activity. After 7 days of storage this activity was $58.7 \%, 52.3 \%$ and 33.6 for dill, peppermint and basil yogurts, respectively. These amounts reduced to $28 \%$ and $46 \%$ after 28 days of storage.

Marhamatizadeh et al. (2013) investigated the effect of olive leaf extract on the growth and viability of Lactobacillus acidophilus and Bifidobacterium bifidum for the production of probiotic milk and yogurt after 21 days of cold storage. $2 \%, 4 \%$ and $6 \%$ of olive leaf extract was used. The results showed that the counts of L. acidophilus and B. bifidum were higher than the control sample when olive leaf extract was used and there was a positive relationship between bacterial growth and the increase in extract levels. The addition of olive leaf extract led to pleasurant taste 
and flavor in yogurts in the presence of L. acidophilus and B. bifidum. It should be mentioned that the sample with $6 \%$ of olive leaf extract had the highest number of probiotic bacteria.

Oh et al. (2016) studied the microbiological and functional properties of set-type yogurt in the presence of a potential prebiotic component of Cudrania tricuspidata leaf extract. $2 \%$ of herbal extract powder was used in this research and antioxidant activity was evaluated on $1^{\text {st }}, 7^{\text {th }}, 14^{\text {th }}, 21^{\text {st }}$ and $28^{\text {th }}$ days. They showed that powder extract in yogurts increased the acidification rate and growth of Streptococcus thermophilus and Lactobacillus bulgaricus in comparison to the control samples.

Joung et al. (2016) investigated the sensory and microbial properties of herbal yogurt with traditional Korean plant extracts Nelumbo nuciferaleaf (NN) and DK) Diospyros kaki Thunb.). The results showed that the herbal extract and storage time influenced several properties of the yogurt and increased the viability of the starter culture and the amount of phenolic components. It should be mentioned that the counts of bacteria in herbal yogurts were the highest (Streptococcus thermophilus and Lactobacillus bulgaricus). The sensory attributes of yogurt samples were evaluated one day after production. Texture, flavor and taste contributed to increased sensory scores after the addition of plant extracts compared to plain samples.

As basil and savory belong to the Lamiaceae family, they have intensive antioxidant activities (Hirasa and Takemasa, 1998). In addition, due to antioxidant activities herbal extracts have positive effects on the functionality of dairy products such as yogurt. Therefore, the aim of this research was to evaluate the effect of adding aqueous extracts of basil and savory on the antioxidant activity, microbial and sensory properties of probiotic yogurt.

\section{MATERIAL AND METHODS}

\section{Materials}

Low-fat milk (Mihan Company, Iran), skimmed milk powder (Saya, Ukrin) and DPPH (Sigma-Aldrich, USA), starter culture (CHR-HANSEN, Denmark) and MRS bile agar (Merck, Germany) were provided for the study.

\section{Preparation of herbal aqueous extract}

The plants used in this study were provided by Firoozeh Medicinal Botanical Garden. The species were then verified and coded in the Iranian Institute of Medicinal Plants with the code numbers 4543 MPIH and 4544 MPIH. Plants were dried at room temperature and away from sunlight. Dried herbs were ground well then $10 \mathrm{ml}$ of distilled water at $70-80^{\circ} \mathrm{C}$ was added per gram of dried herbs. The mixture was stored overnight at $60-70^{\circ} \mathrm{C}$ (Shori and Baba, 2011). An aqueous extraction was obtained by centrifugation ( $2000 \mathrm{rpm}$, $15 \mathrm{~min}$ ). The supernatant was harvested as an aqueous extract of herbs (Shori and Baba, 2014). The extracts were sterilized with a syringe filter $(0.45 \mu \mathrm{L})$ (Das et al., 2010).

\section{Preparation of probiotic herbal yogurt}

Milk with $10.5 \%$ solids not fat was pasteurized at $90^{\circ} \mathrm{C}$ for $5 \mathrm{~min}$ and cooled to $43^{\circ} \mathrm{C}$. Then a yogurt starter (Lactobacillus delbrueckii ssp. bulgaricus and Streptococcus thermophilus) and a probiotic starter (Lactobacillus paracasei ssp. paracasei) were added. Aqueous extracts of basil $(8 \%$ and $10 \% \mathrm{w} / \mathrm{w})$ and savory $(6 \%$ and $8 \% \mathrm{w} / \mathrm{w})$ were added. The samples were packed in 100 gr packages and incubated at $43^{\circ} \mathrm{C}$ until the $\mathrm{pH}$ reached 4.7. Next, the samples were stored at $4 \mathrm{vC}$. The antioxidant activity, microbial and sensory properties of the samples were evaluated on the $1^{\text {st }}, 7^{\text {th }}$, $14^{\text {th }}$ and $21^{\text {st }}$ days. All experiments were performed in triplicate.

\section{Probiotic bacterial counts}

For enumeration of Lactobacillus paracasei ssp. paracasei MRS bile agar (Merck, Germany) was used. The medium was anaerobically incubated at $37^{\circ} \mathrm{C}$ for $72 \mathrm{~h}$ (Sivakumar and Kalaiarasu, 2010).

\section{Acidity measurement}

Acidity was measured according to the AOAC method (AOAC, 2005).

\section{Antioxidant activity}

The yogurt sample $(10 \mathrm{~g})$ was mixed with $2.5 \mathrm{ml}$ distilled water and the yogurt $\mathrm{pH}$ was adjusted to 4.0 using $1 \mathrm{ml} \mathrm{HCl}(0.1 \mathrm{M})$. The yogurt sample was then incubated at $45^{\circ} \mathrm{C}$ for 10 minutes followed by centrifugation $\left(10000 \mathrm{rpm}, 20\right.$ minutes, $\left.4^{\circ} \mathrm{C}\right)$. The supernatant 
was collected and the $\mathrm{pH}$ was adjusted to 7.0 using $\mathrm{NaOH}(0.1 \mathrm{M})$. The neutralized supernatant was recentrifuged $\left(10000 \mathrm{rpm}, 20\right.$ minutes, $\left.4^{\circ} \mathrm{C}\right)$ and the supernatant was used in analysis (Zainoldin and Baba, 2009).

Antioxidant activity was evaluated by the DPPH (1,1-diphenyl-2-picrylhydrazyl radical) method. 250 $\mu \mathrm{L}$ of yogurt extract was added into $3 \mathrm{ml}$ of $60 \mu \mathrm{L}$ in ethanol DPPH (0.0023 gr DPPH in $100 \mathrm{ml}$ of $96 \%$ ethanol) then absorbance was read at $517 \mathrm{~nm}$ after 30 seconds of shaking and incubation in a dark environment at room temperature, then compared to the control sample, which contained $250 \mu \mathrm{L}$ of distilled water instead of yogurt. The inhibition percent was calculated as follows (Apostolidis et al., 2007):

$$
\% \text { inhibition }=1-\left(\mathrm{A}_{\text {sample }} / \mathrm{A}_{\text {control }}\right) \cdot 100
$$

\section{Sensory evaluation}

The organoleptic properties of the yogurts were evaluated by 5 trained panelists. A 5-point hedonic scale (1 - extremely bad and 5 - excellent) was used. The yogurt samples were evaluated according to taste, odor, texture, color and overall acceptance.

\section{Statistical analysis}

The experiment was conducted with completely randomized design. ANOVA and Duncan multiple range tests were used for data analysis, which was carried out using SAS 9.3 Software.

\section{RESULTS AND DISCUSSION}

\section{Microbial characteristics}

Table 1 shows probiotic bacterial counts during the storage of yogurt samples. According to Table 1, after 21 days the highest viability of Lactobacillus paracasei ssp. paracasei was in sample $\mathrm{A}_{4}$ (sample containing $8 \%$ savory extract), which was significant in comparison to other treatments $(p<0.05)$ and the lowest viability was in the control sample, which was also significant $(p<0.05)$. These results showed that adding a herbal extract to probiotic yogurt which contains Lactobacillus paracasei ssp. paracasei significantly increased the viability of probiotic bacteria compared to the control sample $(p<0.05)$. This might be due to the phenolic compounds of herbal extracts that play a stimulating role and enhance the growth of the starter culture of yogurt (Oh et al., 2016) and probiotic bacteria (Marhamatizadeh et al., 2013). Although the population of Lactobacillus paracasei ssp. paracasei decreased significantly in the last stage of storage $(p<0.05)$, which can be because of the accumulation of lactic acid by the starter culture, leading to a reduction in $\mathrm{pH}$ and an increase in acidity (Joung et al., 2016). Increases in $E_{h}$ and the hydrogen peroxide concentration coming from the metabolic activity of bacteria can lead to a reduction in bacterial counts during storage (Dave and Shah, 1997). Michael et al. (2015) reported similar results when investigating the effect of adding herbal extract on the viability of Lactobacillus delbrueckii ssp. bulgaricus and Lactobacillus acidophilus in probiotic non-fat yogurt. Research showed

Table 1. Viability of Lactobacillus paracasei ssp. paracasei during storage (mean $\pm \mathrm{SD}$ )

\begin{tabular}{ccccc}
\hline Sample & $1^{\text {st }}$ day & $7^{\text {th }}$ day & $14^{\text {th }}$ day & $21^{\text {st }}$ day \\
\hline Control & $2 \times 10^{7} \pm 0^{\mathrm{Ad}}$ & $1.3 \times 10^{7} \pm 0.2^{\mathrm{Bd}}$ & $1.09 \times 10^{7} \pm 0.003^{\mathrm{Be}}$ & $0.51 \times 10^{7} \pm 0.001^{\mathrm{Cd}}$ \\
$\mathrm{A}_{1}$ & $3 \times 10^{7} \pm 0.16^{\mathrm{Ac}}$ & $2.65 \times 10^{7} \pm 0.2^{\mathrm{Ac}}$ & $2.33 \times 10^{7} \pm 0.08^{\mathrm{Bd}}$ & $1.97 \times 10^{7} \pm 0.02^{\mathrm{Bc}}$ \\
$\mathrm{A}_{2}$ & $4 \times 10^{7} \pm 0.22^{\mathrm{Ab}}$ & $3.7 \times 10^{7} \pm 0.11^{\mathrm{ABb}}$ & $3.3 \times 10^{7} \pm 0.06^{\mathrm{Bc}}$ & $2.7 \times 10^{7} \pm 0.16^{\mathrm{Cb}}$ \\
$\mathrm{A}_{3}$ & $6 \times 10^{7} \pm 0.23^{\mathrm{Aa}}$ & $5.18 \times 10^{7} \pm 0.04^{\mathrm{Ba}}$ & $4.36 \times 10^{7} \pm 0.01^{\mathrm{Cb}}$ & $3.89 \times 10^{7} \pm 0.07^{\mathrm{Da}}$ \\
$\mathrm{A}_{4}$ & $6.35 \times 10^{7} \pm 0.25^{\mathrm{Aa}}$ & $5.23 \times 10^{7} \pm 0.05^{\mathrm{Ba}}$ & $4.97 \times 10^{7} \pm 0.02^{\mathrm{Ba}}$ & $3.98 \times 10^{7} \pm 0.05^{\mathrm{Ca}}$ \\
\hline
\end{tabular}

Means with different capital letters in each row and means with different small letters in each column show significant differences $(p<0.05)$.

$A_{1}-8 \%$ basil extract, $A_{2}-10 \%$ basil extract, $A_{3}-6 \%$ savory extract, $A_{4}-8 \%$ savory extract. 
Ghaleh Mosiyani, Z., Pourahmad, R., Reza Eshaghi, M. (2017). Investigating the effect of aqueous extracts of basil and savory on antioxidant activity, microbial and sensory properties of probiotic yogurt. Acta Sci. Pol. Technol. Aliment., 16(3), 311-320. http:// dx.doi.org/10.17306/J.AFS.2017.0509

Table 2. The acidity values of the samples during storage (mean $\pm \mathrm{SD}$ )

\begin{tabular}{cllll}
\hline Sample & $1^{\text {st }}$ day & $7^{\text {th }}$ day & $14^{\text {th }}$ day & $21^{\text {st }}$ day \\
\hline Control & $78 \pm 1 / 15^{\mathrm{Cb}}$ & $80 \pm 1^{\mathrm{BCd}}$ & $83 \pm 0 / 58^{\mathrm{ABc}}$ & $84 \pm 1 / 15^{\mathrm{Ac}}$ \\
$\mathrm{A}_{1}$ & $82 \pm 0 / 58^{\mathrm{Ca}}$ & $89 \pm 1^{\mathrm{Bab}}$ & $93 \pm 1 / 15^{\mathrm{Aa}}$ & $94 \pm 2^{\mathrm{Aa}}$ \\
$\mathrm{A}_{2}$ & $83 \pm 1 / 15^{\mathrm{Ca}}$ & $91 \pm 1 / 73^{\mathrm{Ba}}$ & $94 \pm 1 / 15^{\mathrm{ABab}}$ & $95 \pm 1 / 15^{\mathrm{Aa}}$ \\
$\mathrm{A}_{3}$ & $81 \pm 1 / 15^{\mathrm{Bab}}$ & $84 \pm 0^{\mathrm{Bc}}$ & $89 \pm 1^{\mathrm{Ab}}$ & $89 \pm 1 / 15^{\mathrm{Ab}}$ \\
$\mathrm{A}_{4}$ & $80 \pm 1^{\mathrm{Bab}}$ & $88 \pm 2 / 31^{\mathrm{Aab}}$ & $90 \pm 0 / 58^{\mathrm{Aab}}$ & $91 \pm 0 / 58^{\mathrm{Ab}}$ \\
\hline
\end{tabular}

Means with different capital letters in each row and means with different small letters in each column show significant differences $(p<0.05)$.

$A_{1}-8 \%$ basil extract, $A_{2}-10 \%$ basil extract, $A_{3}-6 \%$ savory extract, $A_{4}-8 \%$ savory extract.

that at the end of the storage period, L. bulgaricus and L. acidophilus counts in supplemented yogurts were greater compared with non-supplemented yogurts. L. bulgaricus and L. acidophilus counts in non-supplemented and supplemented yogurts decreased significantly during the 29 days of storage. Jaziri et al. (2009) reported different results when investigating the effect of adding green and black tea on the characteristic microflora of yogurt during fermentation and storage. They concluded that green tea had no significant influence on the characteristic microflora of yogurt $(p>0.05)$.

\section{Acidity}

The results of the acidity of the samples during storage are summarized in Table 2. During storage, the highest acidity belonged to the sample $\mathrm{A}_{2}$, which was significantly different from the other samples except $A_{1}$. The lowest value was related to the control sample, which differed significantly from the others. The addition of the herbal extracts to the probiotic yoghurt greatly increased the acidity of the samples in comparison to the control sample. The reason for this is the fact that milk fermentation with the herbal extracts increased the metabolic activity of the yoghurt bacteria, thus elevating the yoghurt acidity due to the production of organic acids by lactic acid bacteria (Amirdivani and Baba, 2011). Furthermore, the acidity of all samples increased significantly during storage $(p<0.05)$, because as the storage time increased, the lactose fermentation by the starter and probiotic bacteria proceeded, and acidity increased due to the accumulation of organic acids such as lactic acid and formic acid
(Michael et al., 2015). Joung et al. (2016) obtained similar results. The yoghurt acidity increased during storage and all the samples containing the herbal extracts had a higher acidity than the control sample.

\section{Antioxidant activity}

Table 3 represents the inhibitory percentage of DPPH radicals during storage in the samples studied. The highest inhibitory percentage was in sample $\mathrm{A}_{2}$ (sample containing $10 \%$ basil extract) and the lowest was for the control sample, which was significant in comparison to other treatments $(p<0.05)$. The results of this study indicated that adding herbal extracts significantly increased the inhibition of DPPH and thus antioxidant activity $(p<0.05)$. This can be because of the special phytochemical components of the plants (phenolic components) and metabolic products caused by bacterial activity (Thompson et al., 2007). It is worth mentioning that antioxidant activity significantly decreased over time $(p<0.05)$. This reduction may be due to the degradation of phenolic components during refrigerated storage or an increase in milk protein and phenolic component interaction. Continued growth of the bacteria during storage caused changes in phenolic components, which led to a significant increase in antioxidant activity and inhibition of DPPH (Yuksel et al., 2010). Muniandy et al. (2016) studied the influence of adding green, white and black tea on the antioxidant activity of probiotic yogurt during 21 days of storage at $4^{\circ} \mathrm{C}$ and reported similar results. Antioxidant activity was measured using inhibition of the DPPH radical. $2 \% \mathrm{w} / \mathrm{v}$ of tea leaf extracts was added to yogurts. The results revealed that green tea yogurt showed the 

antioxidant activity, microbial and sensory properties of probiotic yogurt. Acta Sci. Pol. Technol. Aliment., 16(3), 311-320. http:// dx.doi.org/10.17306/J.AFS.2017.0509

Table 3. Inhibitory percent of DPPH during storage (mean \pm SD)

\begin{tabular}{crrrc}
\hline Sample & \multicolumn{1}{c}{$1^{\text {st }}$ day } & \multicolumn{1}{c}{$7^{\text {th }}$ day } & $14^{\text {th }}$ day & $21^{\text {st }}$ day \\
\hline Control & $20 \pm 0.68^{\mathrm{Ac}}$ & $10.2 \pm 0.24^{\mathrm{Bd}}$ & $17.2 \pm 0.3^{\mathrm{ABd}}$ & $16.65 \pm 2.8^{\mathrm{ABd}}$ \\
$\mathrm{A}_{1}$ & $86.03 \pm 3.34^{\mathrm{Aa}}$ & $66.6 \pm 0.14^{\mathrm{Bb}}$ & $64.1 \pm 0.13^{\mathrm{Bb}}$ & $55.35 \pm 0.84^{\mathrm{Cb}}$ \\
$\mathrm{A}_{2}$ & $88.8 \pm 0.58^{\mathrm{Aa}}$ & $87.3 \pm 0.31^{\mathrm{Aa}}$ & $87.5 \pm 0.21^{\mathrm{Aa}}$ & $81.43 \pm 1.24^{\mathrm{Aa}}$ \\
$\mathrm{A}_{3}$ & $70.6 \pm 0.68^{\mathrm{Ab}}$ & $51.1 \pm 0.18^{\mathrm{Bc}}$ & $39.3 \pm 0.31^{\mathrm{Cc}}$ & $37.05 \pm 4.47^{\mathrm{Ccd}}$ \\
$\mathrm{A}_{4}$ & $81.4 \pm 0.25^{\mathrm{Aa}}$ & $69.7 \pm 0.66^{\mathrm{Bb}}$ & $41 \pm 0.64^{\mathrm{Cc}}$ & $61.55 \pm 1.18^{\mathrm{Bb}}$ \\
\hline
\end{tabular}

Means with different capital letters in each row and means with different small letters in each column show significant differences $(p<0.05)$.

$A_{1}-8 \%$ basil extract, $A_{2}-10 \%$ basil extract, $A_{3}-6 \%$ savory extract, $A_{4}-8 \%$ savory extract.

highest phenolic content followed by white tea yogurt and black tea yogurt. The lowest inhibitory effect on DPPH was for black tea yogurt $(97.71 \%)$ and the highest was for green tea yogurt $(98.53 \%)$.

\section{Sensory properties}

Sensory scores for the taste and odor of the samples during storage are shown in Table 4 and Table 5. Over time, the highest score of taste and odor was for the control sample, which was significant in comparison to other treatments $(p<0.05)$. The lowest score was for $\mathrm{A}_{1}$ (sample containing $8 \%$ basil extract). Results showed that adding herbal extract to probiotic yogurt significantly decreased the taste and aroma scores in comparison to the control sample ( $p$ $<0.05)$. There is no significant difference between samples during storage $(p>0.05)$, while storage time significantly increased the odor score $(p<0.05)$, except the control sample. Production of lactic acid and aromatic compounds such as acetaldehyde, acetone, acetoyin and diacetyl could define these results (Kaminarides et al., 2004), which showed no change during storage at $4^{\circ} \mathrm{C}$ (Vahcic and Hruskar, 2000). Illupapalayam et al. (2014) investigated the acceptance of probiotic-yogurt with spices and found similar results. Eight types of yogurts with added spice oleoresins (cardamom, cinnamon and nutmeg) and probiotics (Lactobacillus acidophilus and Bifidobacterium) were produced. Sensory evaluation was conducted using a nine-point hedonic scale. Probiotic-yogurt with spices revealed good sensory properties. The best result was for cardamom oleoresin with $L$. acidophilus and Bifidobacterium.

Table 6 shows the texture score of the samples during storage. Over time, the highest score was for the control and sample $A_{3}$ (sample containing 6\% savory

Table 4. Taste score of the samples during storage (mean \pm SD)

\begin{tabular}{ccccc}
\hline Sample & $1^{\text {st }}$ day & $7^{\text {th }}$ day & $14^{\text {th }}$ day & $21^{\text {st }}$ day \\
\hline Control & $5 \pm 0^{\mathrm{Aa}}$ & $4.75 \pm 0.25^{\mathrm{Aa}}$ & $4.67 \pm 0.33^{\mathrm{Aa}}$ & $4.75 \pm 0.25^{\mathrm{Aa}}$ \\
$\mathrm{A}_{1}$ & $3.5 \pm 0.29^{\mathrm{Ab}}$ & $3.5 \pm 0.29^{\mathrm{Ab}}$ & $3.33 \pm 0.33^{\mathrm{Abc}}$ & $4 \pm 0.41^{\mathrm{Aa}}$ \\
$\mathrm{A}_{2}$ & $3.75 \pm 0.48^{\mathrm{Ab}}$ & $3.5 \pm 0.29^{\mathrm{Ab}}$ & $3.33 \pm 0.33^{\mathrm{Abc}}$ & $4.25 \pm 0.48^{\mathrm{Aa}}$ \\
$\mathrm{A}_{3}$ & $4 \pm 0^{\mathrm{Aab}}$ & $3.75 \pm 0.25^{\mathrm{Aab}}$ & $4 \pm 0^{\mathrm{Aab}}$ & $4.5 \pm 0.29^{\mathrm{Aa}}$ \\
$\mathrm{A}_{4}$ & $3.75 \pm 0.25^{\mathrm{Ab}}$ & $4.25 \pm 0.25^{\mathrm{Aa}}$ & $3.67 \pm 0.33^{\mathrm{Ab}}$ & $4 \pm 0.58^{\mathrm{Aa}}$ \\
\hline
\end{tabular}

Means with different capital letters in each row and means with different small letters in each column show significant differences $(p<0.05)$.

$A_{1}-8 \%$ basil extract, $A_{2}-10 \%$ basil extract, $A_{3}-6 \%$ savory extract, $A_{4}-8 \%$ savory extract. 
Ghaleh Mosiyani, Z., Pourahmad, R., Reza Eshaghi, M. (2017). Investigating the effect of aqueous extracts of basil and savory on antioxidant activity, microbial and sensory properties of probiotic yogurt. Acta Sci. Pol. Technol. Aliment., 16(3), 311-320. http:// dx.doi.org/10.17306/J.AFS.2017.0509

Table 5. Odor score of the samples during storage (mean \pm SD)

\begin{tabular}{ccccc}
\hline Sample & \multicolumn{1}{c}{$1^{\text {st }}$ day } & $7^{\text {th }}$ day & $14^{\text {th }}$ day & $21^{\text {st }}$ day \\
\hline Control & $5 \pm 0^{\mathrm{Aa}}$ & $5 \pm 0^{\mathrm{Aa}}$ & $5 \pm 0^{\mathrm{Aa}}$ & $5 \pm 0^{\mathrm{Aa}}$ \\
$\mathrm{A}_{1}$ & $3.25 \pm 0.25^{\mathrm{Bb}}$ & $3.75 \pm 0.25^{\mathrm{ABb}}$ & $3.67 \pm 0.33^{\mathrm{ABb}}$ & $4.25 \pm 0.25^{\mathrm{Aab}}$ \\
$\mathrm{A}_{2}$ & $3.25 \pm 0.25^{\mathrm{Bb}}$ & $3.5 \pm 0.29^{\mathrm{ABb}}$ & $4 \pm 0^{\mathrm{ABb}}$ & $4.25 \pm 0.25^{\mathrm{Aab}}$ \\
$\mathrm{A}_{3}$ & $3.75 \pm 0.25^{\mathrm{Ab}}$ & $4.25 \pm 0.25^{\mathrm{Aab}}$ & $3.67 \pm 0.33^{\mathrm{Ab}}$ & $4.25 \pm 0.48^{\mathrm{Aab}}$ \\
$\mathrm{A}_{4}$ & $3.5 \pm 0.29^{\mathrm{Ab}}$ & $3.5 \pm 0.29^{\mathrm{Ab}}$ & $3.67 \pm 0.33^{\mathrm{Ab}}$ & $4.25 \pm 0.48^{\mathrm{Aab}}$ \\
\hline
\end{tabular}

Means with different capital letters in each row and means with different small letters in each column show significant differences $(p<0.05)$.

$A_{1}-8 \%$ basil extract, $A_{2}-10 \%$ basil extract, $A_{3}-6 \%$ savory extract, $A_{4}-8 \%$ savory extract.

Table 6. Texture score of the samples during storage (mean \pm SD)

\begin{tabular}{|c|c|c|c|c|}
\hline Sample & $1^{\text {st }}$ day & $7^{\text {th }}$ day & $14^{\text {th }}$ day & $21^{\text {st }}$ day \\
\hline Control & $5 \pm 0^{\mathrm{Aa}}$ & $5 \pm 0^{\mathrm{Aa}}$ & $5 \pm 0^{\mathrm{Aa}}$ & $5 \pm 0^{\mathrm{Aa}}$ \\
\hline $\mathrm{A}_{1}$ & $5 \pm 0^{\mathrm{Aa}}$ & $4.75 \pm 0.25^{\mathrm{Aa}}$ & $4.67 \pm 0.33^{\mathrm{Aa}}$ & $5 \pm 0^{\mathrm{Aa}}$ \\
\hline $\mathrm{A}_{2}$ & $5 \pm 0^{\mathrm{Aa}}$ & $4.25 \pm 0.25^{\mathrm{Bb}}$ & $5 \pm 0^{\mathrm{Aa}}$ & $5 \pm 0^{\mathrm{Aa}}$ \\
\hline $\mathrm{A}_{3}$ & $5 \pm 0^{\mathrm{Aa}}$ & $5 \pm 0^{\mathrm{Aa}}$ & $5 \pm 0^{\mathrm{Aa}}$ & $5 \pm 0^{\mathrm{Aa}}$ \\
\hline $\mathrm{A}_{4}$ & $5 \pm 0^{\mathrm{Aa}}$ & $5 \pm 0^{\mathrm{Aa}}$ & $4.67 \pm 0.33^{\mathrm{Aa}}$ & $5 \pm 0^{\text {Aa }}$ \\
\hline
\end{tabular}

Means with different capital letters in each row and means with different small letters in each column show significant differences $(p<0.05)$.

$A_{1}-8 \%$ basil extract, $A_{2}-10 \%$ basil extract, $A_{3}-6 \%$ savory extract, $A_{4}-8 \%$ savory extract.

extract), but was not significant with samples $\mathrm{A}_{1}, \mathrm{~A}_{2}$ and $\mathrm{A}_{4}(p>0.05)$ and the lowest score was for $\mathrm{A}_{2}$ (sample containing $10 \%$ basil extract), which was not significant either $(p>0.05)$. Results showed that adding herbal extract did not significantly influence the texture score in comparison to the control sample ( $p>$ $0.05)$. Although storage time did not have a significant effect on the texture score of all samples $(p>0.05)$, Joung et al. (2016) studied the organoleptic properties of herbal yogurt containing Korean traditional plant extracts (Nelumbo nucifera leaf (NN) and DK) Diospyros kaki Thumb.) and found different results. They showed that the viscosity and textural properties of herbal yogurt were better than plain yogurt, relating to the water-holding capacity, which results in a higher score than plain yogurt.

The color scores of samples are indicated in Table 7 . During storage, the control sample registered the highest score, which was significant $(p<0.05)$. However, the lowest score was for sample $\mathrm{A}_{4}$ (sample containing $8 \%$ savory extract), which was not significantly different to other treatments except the control sample $(p>0.05)$. Results showed that the addition of herbal extracts to the probiotic yogurts led to a significant reduction in color acceptability $(p<0.05)$ and this could be because of the presence of pigments in herbal extracts, which became darker through thermal processing during extraction and consequently darkened the extract and samples. During storage, there was no significant difference between the color of the samples $(p>0.05)$. Marhamatizadeh et al. (2013) investigated the effect of adding $2 \%, 4 \%$ and $6 \%$ olive leaf extract on organoleptic properties of probiotic yogurt during storage but obtained different results. They showed that increasing the concentration of extract led to a better color in the samples. 

antioxidant activity, microbial and sensory properties of probiotic yogurt. Acta Sci. Pol. Technol. Aliment., 16(3), 311-320. http:// dx.doi.org/10.17306/J.AFS.2017.0509

Table 7. Color score of the samples during storage (mean \pm SD)

\begin{tabular}{ccccc}
\hline Sample & $1^{\text {st }}$ day & $7^{\text {th }}$ day & $14^{\text {th }}$ day & $21^{\text {st }}$ day \\
\hline Control & $5 \pm 0^{\mathrm{Aa}}$ & $5 \pm 0^{\mathrm{Aa}}$ & $5 \pm 0^{\mathrm{Aa}}$ & $5 \pm 0^{\mathrm{Aa}}$ \\
$\mathrm{A}_{1}$ & $3.5 \pm 0.29^{\mathrm{Ab}}$ & $4 \pm 0^{\mathrm{Aa}}$ & $3.67 \pm 0.33^{\mathrm{Ab}}$ & $4 \pm 0^{\mathrm{Ab}}$ \\
$\mathrm{A}_{2}$ & $3.5 \pm 0.29^{\mathrm{Ab}}$ & $4 \pm 0^{\mathrm{Aa}}$ & $3.67 \pm 0.33^{\mathrm{Ab}}$ & $4 \pm 0^{\mathrm{Ab}}$ \\
$\mathrm{A}_{3}$ & $3.5 \pm 0.29^{\mathrm{Ab}}$ & $4 \pm 0^{\mathrm{Aa}}$ & $3.67 \pm 0.33^{\mathrm{Ab}}$ & $4 \pm 0^{\mathrm{Ab}}$ \\
$\mathrm{A}_{4}$ & $3.5 \pm 0.29^{\mathrm{Ab}}$ & $3.75 \pm 0.25^{\mathrm{Aa}}$ & $3.67 \pm 0.33^{\mathrm{Ab}}$ & $4 \pm 0^{\mathrm{Ab}}$ \\
\hline
\end{tabular}

Means with different capital letters in each row and means with different small letters in each column show significant differences $(p<0.05)$.

$A_{1}-8 \%$ basil extract, $A_{2}-10 \%$ basil extract, $A_{3}-6 \%$ savory extract, $A_{4}-8 \%$ savory extract.

Table 8. Overall acceptance score of the samples during storage (mean $\pm \mathrm{SD}$ )

\begin{tabular}{ccccc}
\hline Sample & $1^{\text {st }}$ day & $7^{\text {th }}$ day & $14^{\text {th }}$ day & $21^{\text {st }}$ day \\
\hline Control & $5 \pm 0^{\mathrm{Aa}}$ & $5 \pm 0^{\mathrm{Aa}}$ & $4.67 \pm 0.33^{\mathrm{Aa}}$ & $4.75 \pm 0.25^{\mathrm{Aa}}$ \\
$\mathrm{A}_{1}$ & $3.75 \pm 0.25^{\mathrm{ABb}}$ & $4 \pm 0^{\mathrm{ABb}}$ & $3.67 \pm 0.33^{\mathrm{Bb}}$ & $4.25 \pm 0.25^{\mathrm{Aab}}$ \\
$\mathrm{A}_{2}$ & $4 \pm 0^{\mathrm{ABb}}$ & $3.75 \pm 0.25^{\mathrm{Bbc}}$ & $4 \pm 0^{\mathrm{ABab}}$ & $4.25 \pm 0.25^{\mathrm{Aab}}$ \\
$\mathrm{A}_{3}$ & $4 \pm 0.41^{\mathrm{Ab}}$ & $4 \pm 0^{\mathrm{Ab}}$ & $4 \pm 0^{\mathrm{Aab}}$ & $4.25 \pm 0.25^{\mathrm{Aab}}$ \\
$\mathrm{A}_{4}$ & $3.75 \pm 0.25^{\mathrm{Ab}}$ & $4.25 \pm 0.25^{\mathrm{Ab}}$ & $4 \pm 0^{\mathrm{Aab}}$ & $4 \pm 0.41^{\mathrm{Aab}}$ \\
\hline
\end{tabular}

Means with different capital letters in each row and means with different small letters in each column show significant differences $(p<0.05)$.

$A_{1}-8 \%$ basil extract, $A_{2}-10 \%$ basil extract, $A_{3}-6 \%$ savory extract, $A_{4}-8 \%$ savory extract.

The overall acceptance score of yogurt samples during storage is presented in Table 8. The highest overall acceptance score was for the control sample, which was significant $(p<0.05)$, and the lowest was for sample $A_{1}$ (sample containing $8 \%$ basil extract), which did not differ significantly from other treatments, except the control sample $(p>0.05)$. The results indicate that adding herbal extract to probiotic yogurt significantly decreased the overall acceptance in comparison to the control sample $(p<0.05)$. This might be due to the reduction in the acceptability of taste, odor and color of herbal yogurts, which led to a reduction in overall acceptance. However, time significantly influenced the overall acceptances of samples $\mathrm{A}_{1}$ and $\mathrm{A}_{2}$ $(p<0.05)$, which was not significant for samples $\mathrm{A}_{3}$ and $\mathrm{A}_{4}(p>0.05)$. Owing to their antioxidant effects, herbal extracts increase the functionality of products such as probiotic yogurt. Therefore, it could be stated that this functionality could cover the mentioned undesirable taste and odor. Furthermore, this odor and taste were compared with those of the control sample. This product itself does not have an undesirable odor and taste, as can be seen the sensory evaluation, and the products containing the extract obtained relatively scores in terms of overall acceptability.

\section{CONCLUSION}

Since the addition of prebiotic compounds leads to the probiotics and health features of the product being maintained during storage, herbal extracts are strongly recommended due to their growth stimulator effects. Adding these extracts can increase the functional properties of the yogurt samples by enhancing the inhibitory effect on DPPH. On the other hand, despite a reduction in the taste, odor, color and overall 

antioxidant activity, microbial and sensory properties of probiotic yogurt. Acta Sci. Pol. Technol. Aliment., 16(3), 311-320. http:// dx.doi.org/10.17306/J.AFS.2017.0509

acceptance attributes of the samples, these functional yogurts are highly recommended due to their having probiotic bacteria and better DPPH inhibition. It is worth mentioning that $8 \%$ of savory extract had the greatest effect on probiotic bacterial survival, the highest antioxidant activity was related to probiotic herbal yogurt containing $10 \%$ basil extract and the highest sensory score was registered for sample containing $6 \%$ savory extract.

\section{REFERENCES}

Amirdivani, S., Baba, A. S. (2011). Changes in yogurt fermentation characteristics, and antioxidant potential and in vitro inhibition of angiotensin-1 converting enzyme upon the inclusion of peppermint, dill and basil. LWT - Food Sci. Technol., 44, 1458-1464. http://doi. org/10.1016/j.lwt.2011.01.019

Antolovich, M., Prenzler, P., Patasalides, E. (2002). Methods for testing and antioxidant activity. Analyst, 127, 183-198.

AOAC .(2005). Official methods of analysis, ice cream and frozen dessert. 18th editions (pp. 93-96). Washington: Association of Official Analytical Chemists.

Apostolidis, E., Kwon, Y. I., Shetty, K. (2007). Inhibitory potential of herb, fruit and fungal- enriched cheese against key enzymes linked to type 2 diabetes and hypertension. Innov. Food Sci. Emerg. Technol., 8, 46-54. http://doi.org/10.1016/j.lfset.2006.06.001

Das, K., Tiwari, R. K. S., Shrivastava, D. K. (2010). Techniques for evaluation of medicinal plant products as antimicrobial agent: current methods and future trends. J. Med. Plants Res., 4, 104-111. http://doi.org/10.5897/ JMPR09.030

Dave, R. I., Shah, N. P. (1997). Viability of yogurt and probiotic bacteria in yogurts made from commercial starter cultures. Int. Dairy J., 7, 31-41. http://dx.doi. org/10.3168/jds.S0022-0302(00)75070-3

Guarner, F., Khan, A. C., Carisch, J., Eliakim, R., Gangl, A., Thomson, A., ..., Mair, T. L. (2008). World Gastroenterology Organisation Practice: Guideline Probiotic and Prebiotic. J. Clin. Gastroenterol., 1-22.

Hirasa, K., Takemasa, M. (1998). Spices science and technology. New York: CRC Press.

Illupapalayam, V. V., Smith, S. C., Gamlath, S. (2014). Consumer acceptability and antioxidant potential of probiotic-yogurt with spices. LWT - Food Sci. Technol., 55, 255-262. http://doi.org/10.1016/j.lwt.2013.09.025
Jaziri, I., Ben Salma, M., Mhadhbi, H. Urdaci, M. C., Hamdi, M. (2009). Effect of green and black teas ( $\mathrm{Ca}$ mellia sinensis L.) on the characteristic microflora of yogurt during fermentation and refrigerated storage. Food Chem., 112, 614-620. http://doi.org/10.1016/j. foodchem.2008.06.017

Joung, J. Y., Lee, J. Y., Ha, Y. S., Shin, Y. K., Kim, S. H., Oh, N. S. (2016). Enhanced Microbial, Functional and Sensory Properties of Herbal Yogurt Fermented with Korean Traditional Plant Extracts. Korean J. Food Sci. Anim. Res., 36, 90-99. http://doi.org/10.5851/ kosfa.2016.36.1.90

Kaminarides, S., Stamou, P., Massouras, T. (2004). Comparison of the characteristics of set type yoghurt made from ovine milk of different fat content. Int. J. Food Sci. Technol., 42, 1019-1028. http://doi. org/10.1111/j.1365-2621.2006.01320.x

Kulisic, T., Radonic, A., Katalinic, V. (2004). Use of different methods for testing antioxidative of oregano essential oil. Food Chem., 85, 633-640. http://doi.org/10.1016/j. foodchem.2003.07.024

Marhamatizadeh, M. H., Ehsandoost, E., Gholami, P., Davanyan Mohaghegh, M. (2013). Effect of olive leaf extract on growth and viabiolity of Lactobacillus acidophilus and Bifidobacterium bifidum for production of probiotic milk and yogurt. Int. J. Farm. Allied Sci., 2, 572-578.

Michael, M., Phebus, R. K., Schmidt, K. A. (2015). Plant extract enhances the viability of Lactobacillus delbrueckii subsp. bulgaricus and Lactobacillus acidophilus in probiotic nonfat yogurt. Food Sci. Nutr., 3, 48-55. http:// doi.org/10.1002/fsn3.189

Mishra, V., Prasad, D. N. (2005). Application of invitro methods for selection of Lactobacillus casei strains as potential probiotics. Int. J. Food Microbiol., 103, 109115. http://doi.org/10.1016/j.ijfoodmicro.2004.10.047

Muniandy, P., Shori, A. B., Baba, A. S. (2016). Influence of green, white and black tea addition on antioxidant activity of probiotic yogurt during refrigerated storage. Food Pack. Shelf Life, 8, 1-8. http://doi.org/10.1016/j. fps1.2016.02.002

Oh, N. S., Lee, J. Y., Joung, J. Y., Kim, K. S., Shin, Y. K., Lee, K. W. (2016). Microbiological characterization and functionality of set-type yogurt fermented with potential prebiotic substrates Cudrania tricuspidata and Morus alba L. leaf extracts. J. Dairy Sci., 99, 1-12. http://doi. org/10.3168/jds.2015-10814

Ross, R. P., Fiterald, G., Collins, K., Stanton, C. (2002). Cheese delivering biocultures-probiotic cheese. Aust. J. Dairy Technol., 57, 71-78. 
Sajjadi, S. E. (2006). Analysis of the essential oils of two cultivated basil (Ocimum basilicum L.) from Iran. DARU J. Facul. Pharm., 14, 128-130.

Sefidkon, F., Jamzad, Z. (2005). Chemical composition of the essential oil of three Iraninan Satureja species $(S$. muticca, S. macrantha and S. intermedia). Food Chem., 91, 1-4. http://doi.org/10.1016/j.foodchem.2004.01.027

Shori, A. B., Baba, A. S. (2011). Viability of lactic acid bacteria and sensory evaluation in Cinnamomum verum and Allium stavium bioyogurts made from camel and cow milk. J. Assoc. Arab Univ. Basic Appl. Sci., 11, 50-55. https://doi.org/10.1016/j.jaubas.2011.11.001

Shori, A. B., Baba, A. S. (2014). Comparative antioxidant activity, proteolysis and invitro a-amylase and a-glucosidase inhibition of Allium sativum-yogurts made from cow and camel milk. J. Saudi Chem. Soc., 18, 456-463. http://doi.org/10.1016/j.jscs.2011.09.014

Singh, G., Maurya, S., de Lampasona, M., Catalan C. A. N. (2007). A comparison of chemical, antioxidant and antimicrobil studies of cinnamon leaf and bark volatile oils, oleoresins and their constituents. Food Chem. Toxicol., 45, 1650-1661. https://doi.org/10.1016/j. fct.2007.02.031

Sivakumar, N., Kalaiarasu, S. (2010). Microbiological approach of curd samples collected from different locations of Tamilnadu India. Int. J. Curr. Res., 2, 27-30.
Stoilova, A., Krastano, A., Dtoyanova, P., Senev, P., Farfova, S. (2007). Antioxidant activity of ginger extract (Zingiber officinale). Food Chem., 10, 764-770. http:// doi.org/10.1016/j.foodchem.2006.06.023

Thompson, J. L., Lopetcharat, K., Drake, M. A. (2007). Preferences for commercial strawberry drinkable yogurts among African Amierican, Caucasian, and Hispanic consumers in the United States. J. Dairy Sci., 90, 4974-4987. http://doi.org/10.3168/jds.2007-0313

Vahcic, N., Hruskar, M. (2000). Slovenian fermented milk with probiotics. Izvorn. Znanstv. Prispev., 76, 41-46.

Yasin, N., Abou-Taleb, M. (2007). Antioxidant and antimicrobial effects of marjoram and thyme in coateg refrigerated semi fried mullet fish fillets. World J. Dairy Food Sci., 2, 1-9.

Yuksel, Z., Arci, E., Erdem, Y. K. (2010). Characterization of binding interactions between green tea flavonoids and milk proteins. Food Chem., 121, 450-456. http://doi. org/10.1016/j.foodchem.2009.12.064

Zainoldin, K. H., Baba, A. S. (2009). The effect of Hylocereus polyrhizus and Hylocereus undatus on physicochemical, proteolysis and antioxidant activity in yogurt. World Acad. Sci. Eng. Technol., 76, 361-366. 